\title{
The Influence of Corporate Culture on Employee Commitment to the Organization
}

\author{
Ezekiel Saasongu Nongo ${ }^{1} \&$ Darius Ngutor Ikyanyon ${ }^{1}$ \\ ${ }^{1}$ Department of Business Management, Benue State University, Makurdi, Nigeria \\ Correspondence: Darius Ngutor Ikyanyon, Department of Business Management, Benue State University, \\ Makurdi, Nigeria. Tel: 234-803-586-8549. E-mail: ikyanyondarius@gmail.com
}

Received: July 30, 2012 Accepted: September 5, 2012 Online Published: October 18, 2012

doi:10.5539/ijbm.v7n22p21 URL: http://dx.doi.org/10.5539/ijbm.v7n22p21

\begin{abstract}
Corporate culture is a critical factor in enhancing the attainment of organizational goals and objectives. This study examined the impact of four corporate cultural variables namely, involvement, consistency, adaptability, and mission on employee commitment to the organization. Data was collected from 134 employees of 18 selected SMEs in Makurdi metropolis. Data was collected through the use of standardized questionnaires measuring corporate culture and organizational commitment. Analysis of data was done using pearson correlation coefficient, regression analysis, independent T-test and ANOVA. The study found that involvement and adaptability significantly correlated with commitment, while consistency and mission did not correlate with commitment. The implications of the findings were discussed and recommendations made.
\end{abstract}

Keywords: corporate culture, involvement, consistency, adaptability, mission, commitment, SMEs, Nigeria

\section{Introduction}

Organizational commitment which is defined as the degree to which an employee identifies with the organization and wants to continue actively participating in it (Newstrom and Davies, 2002) is an interesting topic in the field of organizational behaviour. The interest in this topic is due to the fact that employee commitment is vital to contemporary organizational success (Pfeffer, 1998). The stronger an employee's commitment to the organization, the less likely the person is to quit (Guest, 1991; Shore and Martin, 1989). Strong commitment is also correlated with organizational citizenship (Handsoff, 1994; Shore and Wayne, 1993), job satisfaction (Anis et al. 2011; Sharma and Bajpai, 2010), job performance (Bergman et al., 2000; Mathieu and Zajac, 1990; Samad, 2007; Ward and Davis, 1995; Yousef, 2000) and employee retention (Anis et al. 2011).

As a result of the importance of organizational commitment, several studies (Allen and Meyer, 1990; Chen et al., 2006; Clugston, 2000; DeCottis and Summers, 1987; Iverson and Roy, 1994; Lok and Crawford, 2001; Khan et al., 2011; Michaels, 1994; Salami, 2008; Steinhaus and Perry; Taormina, 1999) have sought to identify its causal antecedents. However, corporate culture has received relatively low levels of empirical investigation among the possible antecedents of organizational commitment (Lok and Crawford, 2004). The authors (Lok and Crawford) expressed their surprise that corporate culture was not mentioned in Mathieu and Zajac's (1990) comprehensive meta-analysis and review of the antecedents and correlates of organizational commitment.

Corporate culture affects the way in which people behave in an organization. Corporate culture can be viewed as the unique pattern of shared values, attitudes, rituals, beliefs, norms, expectations, socialization, and assumptions of employees in the organization (Armstrong, 2009; Chatman and Caldwell, 1991; Eldridge and Crombie, 1974; Furnham and Gunter, 1993; Schein, 1992). Corporate culture is therefore equated with the personality of the organization, depicting employee behaviour even when they are not instructed on what to do (Hellriegel et al. 2004).

Research evidence (Clugston, 2000; Deal and Kennedy, 1982; Denison, 1984; Denison, 1990; Kotter and Heskett, 1992; Peters and Watermann, 1982; Rowe et al., 1992; Wasti, 2003) suggests that corporate culture exerts a considerable influence on organizational behaviour, especially in the areas of efficiency, effectiveness, and commitment. This means that by developing an appropriate corporate culture, organizations can achieve success. There is therefore the need to study the influence of corporate culture on employee commitment to the organization. 
It is assumed that corporate culture influences employees' sense of engagement, identification and belonging to the organization. Lok and Crawford (2004) observed that such sentiments might reasonably be expected to affect commitment. Due to the dearth of research on organizational commitment in Nigeria (Salami, 2008) and the lack of adequate research attention given to the effect of corporate culture on organizational commitment globally as evidenced in previous research, there exists a huge research gap that this study intends to fill.

The study is significant for a rapidly developing country such as Nigeria as there is great need to understand how corporate culture influences employee attitude of commitment to the organization. This could lead to improvements in workplaces to help employees become more committed to their jobs. Theoretically, it is imperative to enhance our understanding of how corporate culture affects organizational commitment in a non-western country. Finally, the study will help managers in decision making especially in the areas of recruitment, selection, promotion, training, motivation, and instituting change in the organization.

\section{Corporate Culture and Organizational Commitment}

The effectiveness of an organization is influenced by corporate culture, which affects the way managerial functions of planning, organizing, staffing, leading, and controlling are carried out (Ikyanyon and Gundu, 2009). Organizational commitment is viewed as the psychological strength of an employee's attachment and involvement with the organization (Mowday et al., 1979). A committed employee is determined to stay with the organization irrespective of whether the organization is in a favourable or unfavourable state (Allen and Meyer, 1990). Corporate culture is pervasive and powerful as it either encourages or hampers change in the organization. For employees, corporate culture is either the glue that binds employees to the organization or the wind that blows them away.

Corporate culture is important in enhancing organizations' key capabilities and how they function (Chen, 2004; Nazir, 2005; O'Reilly, 1989; Silverthorne, 2004). Culture is also essential in determining how well an employee fits into the organizational context. Meanwhile, the importance of a good fit between an employee and the organization cannot be overemphasized (O'Reilly et al., 1991). Deal and Kennedy (1982) argue that corporate culture affects the commitment of employees within the organization and the strength of organizational commitment is correlated with the strength of corporate culture. A strong corporate culture enables employees understand the goals of the organization, and as they work towards organizational goals, their level of commitment increases.

Corporate culture is vital in developing and sustaining employee commitment and intensity levels that is often characteristic of successful organizations (Deal and Kennedy, 1982; Silverthorne, 2004). In addition, shared values which are an aspect of corporate culture enhance employees' identification and attachment to the organization (Sathe, 1983). This clearly shows that employees elect to be committed to organizations whose values they share (Bretz and Judge, 1994; Nazir, 2005). Similarly, Deal and Kennedy (1988) state that symbols are important in achieving organizational commitment.

Although empirical research has been carried out on corporate culture and employee commitment to the organization, there has been little evidence to prove the effect of corporate culture on organizational commitment (McKinon et al., 2003). In a study of Hong Kong and Australian managers, Lok and Crawford (2004) found a positive effect of corporate culture on organizational commitment. Zain et al. (2009) examined the effect of four dimensions of corporate culture namely teamwork, communication, reward and recognition, and training and development on organizational commitment and found that all the four dimensions of corporate culture were important determinants of organizational commitment. While Mahmudah (2012) report a significant relationship between corporate culture and organizational commitment, research by Lahiry (1994) showed only a weak association between corporate culture and organizational commitment. This study seeks to further examine this relationship with particular reference to the Nigerian work environment.

\section{Measures and Hypotheses}

The measures for this study are corporate culture and organizational commitment. The study seeks to examine the relationship between the two variables, with corporate culture viewed as the independent variable while organizational commitment is viewed as the dependent variable.

\subsection{Corporate Culture}

The definition of corporate culture, initially focused on distinguishing levels of corporate culture and classifying culture as strong or weak cultures (Handy, 1976; Peters and Waterman, 1982). Many definitions of corporate culture gave primacy to the cognitive components such as assumptions, beliefs, and values (Denison, 1990; Handy, 1993; Mclean and Marshal, 1993). Other definitions include behaviours and artifacts, leading to a 
common distinction between the visible and the hidden levels of corporate culture (Schein, 1985).

There are two perspectives in understanding corporate culture, the symbolic interactionist perspective (Blumer, 1969; Coolgy, 1922; Mead, 1934) and the social - anthropological perspective (Kluckhohn, 1951). The symbolic interactionist perspective view the exchange of symbols as the basis for the shared meaning for a group of social actors. Recognizing and using these symbols entails developing a 'self' defined in terms of culturally specified symbols. Stemming from this perspective myths (Eliade, 1959), archetypes (Mitroft, 1984), and stories and ideologies (Starbuck, 1982) are often useful in explaining objectively organizational features as they embody and articulate the identity of organizational members. The social anthropological perspective view culture as socially constructed. The two perspectives have taken a contingency approach (Lawrence and Lorch, 1967) that argue that different environmental conditions give rise to and are consistent with different patterns of behaviour and cultures within organizations.

Corporate culture measures have been validated as involvement, consistency, adaptability and mission traits (Coffey, 2003; Denison 1990; Fey and Denison, 2003; Miller, 2004). Involvement trait measures the extent to which the participation of employees in decision making results to a consensus of responsibility and commitment to organizational goals. Consistency trait measures how employees shared values, beliefs and symbols result to coordinated actions. Adaptability trait measures how organizations system of behaviours and structures increase their capacity to survive in their environment. Shared mission trait measures how employees shared understanding of the function, purpose and objectives of organizations result to corporate commitment and effective performance. Corporate culture will be measured in this study using the four corporate cultural traits.

\subsection{Organizational Commitment}

Organizational commitment remains a contested construct that has been conceptualized and measured differently. It is viewed from behavioural and attitudinal perspectives (Lok and Crawford, 2004). Behavioural commitment is concerned with the process by which an employee becomes part of a particular organization and appropriate behaviour exhibited by the employee (Meyer and Allen, 1991). On the other hand, attitudinal commitment views organizational commitment in terms of the relationship between an employee and the organization, and the extent to which the employee and the organization share the same goals and values (Meyer and Allen, 1991).

Despite the dichotomy between behavioural and attitudinal commitment, measures on the basis of attitudinal perspective have been most frequently validated and used in previous research (Lok and Crawford, 2004; Meyer and Allen, 1997; Price and Mueller, 1981; Steers, 1977). Based on attitudinal commitment, Mowday et al. (1979) define organizational commitment as the relative strength of an individual's identification with, and involvement in a particular organization. This can be characterized by three related factors: a strong belief in and acceptance of the organization's goals and values; a willingness to exert considerable effort on behalf of the organization; and a strong desire to maintain membership in the organization. Lok and Crawford (2004) argue that Mowday et al.'s (1982) conceptualization of organizational commitment is consistent with the attitudinal perspective. This conceptualization is measured via Mowday et al.'s (1979) organizational commitment questionnaire (OCQ) which will be used in this study.

Based on the measures of the study, the following hypotheses were formulated and tested.

H1: There is no significant relationship between employees' involvement in decision making and employees' commitment to the organization.

H2: There is no significant relationship between consistency and employees' commitment to the organization.

H3: There is no significant relationship between organizations ability to adapt to their environment and employees' commitment to the organization.

H4: There is no significant relationship between employees' identification with organizational mission and employees' commitment to the organization.

\section{Participants and Methods}

The study adopted the survey research design since data were collected from the respondents without imposing any treatment on them. The participants for the study were made up of 134 employees from 18 selected small and medium scale enterprises (SMEs) in Makurdi metropolis. The SMEs selected for the study cut across different industries, ranging from agro-allied to food and beverages industries. The small enterprise is an establishment with the total cost of capital of over One Million, Five Hundred Thousand Naira (\$9375) but not more than Fifty Million Naira (\$312500), excluding the cost of land and a labour size of 10 to 100 workers, while a medium enterprise is a business with a total capital base of above Fifty Million Naira (\$9375) but not exceeding Two Hundred Million Naira $(\$ 125000)$, but excluding land and labour size of 100 to 300 workers 
(Kpelai, 2009). However, Ekpenyong and Nyong (1992) observed that in Nigeria, there is no clear cut definition that distinguishes small enterprises from medium enterprises. This is because of the fluid nature that reflects the characteristics of typical Nigerian small enterprises in terms of their capital base, number of employees and annual turnovers.

In order to enhance ethical standards in research, participation in the study was voluntarily, with the purpose of the study made known to participants. The SMEs sector was considered appropriate for the study due to its importance to the industrialization of the Nigerian economy. It is hoped that if SMEs maintain a positive corporate culture that will elicit employee commitment, they will be better placed to contribute to the attainment of vision 20:2020 of the federal government of Nigeria. By vision 20:2020, Nigeria hopes to be among the top 20 economies of the world by the year 2020. The performance of SMEs is therefore key to attaining this vision.

Out of the 134 participants for the study, $50.8 \%$ were male while $49.2 \%$ were female. The highest educational qualification of most of the respondents $(53 \%)$ was the senior secondary certificate examination (SSCE). This is not surprising since most SMEs in Nigeria employ mostly unskilled labour due to the cheapness of this category of workforce. In the same vein, majority of the participants (60.3\%) were junior staff in their organizations. Most of them (69.4\%) had working experience of between 1 to 5 years with their organizations and were not married $(58.2 \%)$, while majority of them $(37.3 \%)$ were between the ages 18 and 25 years.

\section{Instrumentation}

Data was collected for this study with the use of standardized questionnaires. Corporate culture was measured using some items adapted from the Denison organizational culture survey (Denison, 1990). The instrument has four sub scales measuring the four main cultural traits namely, involvement, consistency, adaptability, and mission. The reliability coefficients of the sub scales were $.877, .889, .874$, and .864 respectively. The instrument has been used with success among Nigerian samples (Nongo, 2011).

Organizational commitment was measured using Mowday et al.'s (1979) organizational commitment questionnaire (OCQ). The instrument contains 15 items that measure the employees' level of identification with their organizations on a 7-point Likert type scale anchored from 1-strongly disagree to 7- strongly agree. Results are then summed and divided by 15 to arrive at a summary indicator of employee commitment. The OCQ has wide acceptance in organizational behaviour research (Benkhoff, 1997; Mowday, 1999; Samad, 2011; Shore and Martin, 1989) and has been used with success among Nigerian samples (Salami, 2008). The reliability coefficient of the instrument was .849.

Data was also collected on the demographic characteristics of respondents such as sex, education, job level, experience, marital status, and age. This was to enable us assess the influence of demography on the variables studied. Pearson product moment correlation coefficient, regression, independent sample T-test, and ANOVA were the tools for data analysis.

\section{Results}

The result of the Pearson correlation between independent variables (involvement, consistency, adaptability, and mission) and the dependent variable (employee commitment) presented in table 1 shows a significant and positive relationship between involvement and commitment $(r=.179, p<.05)$. The relationship between consistency and commitment was however not significant but positive $(r=.050, p>.05)$. There was a significant and positive relationship between adaptability and commitment $(r=.233, p<.01)$, while the relationship between mission and commitment was not significant and negative $(r=-050, p>.05)$.

Table 1. Correlation matrix

\begin{tabular}{|c|c|c|c|c|c|c|c|c|c|c|c|}
\hline & Variables & 1 & 2 & 3 & 4 & 5 & 6 & 7 & 8 & 9 & 10 \\
\hline 1 & Involvement & & & & & & & & & & \\
\hline 2 & Consistency & .065 & & & & & & & & & \\
\hline 3 & Adaptability & .152 & $.193 *$ & & & & & & & & \\
\hline 4 & Mission & $.320 * *$ & $.180 *$ & $-.187^{*}$ & & & & & & & \\
\hline 5 & Sex & -.105 & .090 & -.030 & .040 & & & & & & \\
\hline 6 & Education & .156 & -.036 & -.032 & -.022 & $-.180 *$ & & & & & \\
\hline 7 & Job Level & -.139 & $.234^{* *}$ & .077 & .049 & $.175^{*}$ & $-.635^{* *}$ & & & & \\
\hline 8 & Experience & .103 & $-.264 * *$ & -.062 & .008 & -.170 & $.265^{* *}$ & $-.590 * *$ & & & \\
\hline 9 & Marital Status & -.041 & -.015 & .049 & .019 & .045 & .114 & -.118 & $.275^{* *}$ & & \\
\hline 10 & Age & -.045 & -.003 & .068 & -.048 & -.098 & $.204^{*}$ & $-.227 * *$ & $.259 * *$ & $.601 * *$ & \\
\hline 11 & Commitment & .179 & .050 & $.232 * *$ & -0.50 & .040 & -.083 & .066 & .095 & $.229 * *$ & .109 \\
\hline
\end{tabular}


The regression analysis was used to further analyze the relationship between the variables. The result indicates a significant relationship between involvement and commitment $\left(R^{2}=.032, F_{1,130}=4.308, p<.05\right)$. As usual, the relationship between consistency and commitment was not significant $\left(R^{2}=.003, F_{1,129}=.326, p>.05\right)$. While the relationship between adaptability and commitment was significant $\left(R^{2}=.054, F_{1,124}=7.084\right)$, the relationship between mission and commitment was not significant $\left(R^{2}=.003, F_{1,124}=.315, p>.05\right)$.

The beta values for the corporate cultural variables predicting employee commitment indicate that adaptability predicted commitment among the respondents studied more than any other corporate cultural variable $(\beta=.305)$. This was followed by involvement $(\beta=.133)$, mission $(\beta=.037)$, and consistency $(\beta=-.022)$.

The influence of the demographic variables was not much on both the independent and dependent variables. There was a significant and positive relationship between marital status and commitment $(r=.229, p<.01)$, with the married respondents demonstrating more commitment (Mean $=54.82, t=-2.635, p<.01)$. The relationship between job level and consistency was also significant and positive $(r=.234, p<.01)$. The middle management employees rated higher for consistency (Mean $\left.=31.94, F_{2,127}=4.336, p<.05\right)$. The relationship between experience and consistency was significant but negative $(r=-.264, p<.01)$, with consistency negatively affected most by employees with $1-5$ years of working experience (Mean $=35.28, F_{4,125}=2.616, p<.05$ ). The other demographic characteristics of respondents did not influence the variables studied.

\section{Implications}

The study found a significant and positive relationship between involvement and commitment. This means that employees are committed to their organizations when they are involved in decision making. The key success factors for organizations today are employee empowerment, teamwork, and employee development. These enable managers and employees more committed to work and feel that they own a piece of the organization. People at all levels feel that they have at least some inputs into decisions that will affect their work and that their work is directly connected to the goals of the organization.

There was no significant relationship between consistency and commitment. As much as organizations try to maintain a strong culture by being highly consistent, well coordinated, and well integrated, this does not impact significantly on the level of employee commitment. Employees prefer to be given the freedom to do the job rather than being compelled to do it in a rigid manner. The key success factor for organizations today is flexibility rather than consistency. While organizations need to maintain a strong corporate culture, they need to be flexible.

Furthermore, the positive relationship between adaptability and employee commitment has been well established in this research. Adaptability predicts employee commitment more than any other corporate cultural variables. Employees are more committed to organizations that adapt to changing circumstances.

The study however found no significant relationship between mission and commitment. This means that employees' identification with the purpose, mission, and goals of the organization does not elicit commitment to the organization. Ironically, most employees of SMEs in Nigeria are not concerned with the mission of their organization but are concerned with where they can work and earn a living, irrespective of what the organization stands for. Moreover, most SMEs do not clearly define the mission of the organization, which makes employees unaware of the future direction of the organization.

The influence of demographic characteristics on the study variables needs to be discussed. While the influence was not much, the issue that stands out is the significant relationship between marital status and commitment. Married employees are more committed to their organizations because of the family responsibilities they shoulder. As a result, they become more committed to the organization not necessarily because they cherish the organization but because they need to earn money to cater for their family.

\section{Conclusion}

Employees' involvement in decision making as well as the organization's ability to adapt to changing circumstances impact positively on employee commitment to the organization. This is however not the case for organizations that are consistent, as well as employees' identification with the mission of the organization. We therefore conclude that while corporate culture is important in improving the level of employee commitment to the organization, not all corporate cultural measures impact on employee commitment.

We therefore recommend that managers of SMEs in Nigeria should as much as the context permit allow employees to be actively involved in decision making in their organizations. This would spur employees' commitment towards the attainment of corporate objectives. Secondly, managers of SMEs in Nigeria should define the mission of their organization clearly and communicate same to employees at all times. As employees 
understand the goals of the organization and work towards their attainment, their level of commitment increases. Also, managers of SMEs should encourage innovation and teamwork among employees. This will enable employees adapt in an environment of change, thereby improving their level of commitment. Furthermore, managers of SMEs in Nigeria should as much as possible encourage flexibility in the performance of tasks in the organization. This will make the job more challenging for employees as this will enhance their commitment to the organization. Finally, employees of SMEs in Nigeria should view their organization as their own and be more committed to the success of their organization to enable the organization contribute to their personal success.

\section{References}

Allen, N. J., \& Meyer, J. P. (1990). The measurement and academic of affective, normative and continuous commitment to the organization. Journal of Occupational Psychology, 63(1), 1-18. http://dx.doi.org/10.1111/j.2044-8325.1990.tb00506.x

Armstrong, A. (2000). Armstrong's Handbook of HRM Practice (11th Ed.) London: Kogan Page.

Benkhoff, B. (1997). Ignoring commitment is costly: New approaches establish the missing ling between commitment and performance. Human relations, 50, 701-726. http://dx.doi.org/10.1177/001872679705000604

Blumer, H. (1969). Symbolic interactionism: Perspective and method. Englewood Cliffs NJ: Prentice Hall.

Bretz, R. D., \& Judge, T. A. (1994). Person organization fit and the theory of work adjustment: Implications for satisfaction, tenure and career success. Journal of Vocational Behaviour, 44, 32-54. http://dx.doi.org/10.1006/jvbe.1994.1003

Chen, Y. L. (2004). Examining the effect of organization culture and leadership behaviours on organizational commitment, job satisfaction and job performance at small and middle firms of Taiwan. The Journal of American Academy of Business, 5(2-2), 432-438.

Clugston, M. (2000). The mediating effects of multidimensional commitment on job satisfaction and intent to leave. Journal of Organizational Behaviour, 21, 477-486. http://dx.doi.org/10.1002/(SICI)1099-1379(200006)21:4<477::AID-JOB25>3.0.CO;2-7

Coffey, V. (2003). The organizational culture and effectiveness of companies involved in public sector housing in Hong Kong. CIB TG International conference, October, 27-43.

Coolgy, A. (1922). Human nature and the social order. New York: Schuster.

Deal, T., \& Kennedy, A. (1982). A Corporate Culture. Reading, M. A. Addison Wesley.

Deal, T. E., \& Kennedy, A. A. (1988). Corporate Culture: The rites and rituals of corporate life. London: Penguin.

DeCotiis, T., \& Summers, T. (1987). A path analysis of a model of the antecedents and consequences of $\begin{array}{llll}\text { organizational } \quad \text { commitment. } & \text { Human }\end{array}$ http://dx.doi.org/10.1177/001872678704000704

Denison, D. R. (1984). Bringing corporate culture to the bottom line. Organizational Dynamics, 13(2), 5-22. http://dx.doi.org/10.1016/0090-2616(84)90015-9

Denison, D. R. (1990). Corporate Culture and Organizational Effectiveness. New York: Wiley \& Sons.

Ekpenyong, D. R., \& Nyong, M. O. (1992). Small and medium scale enterprises in Nigeria. AERC Research Paper, 16.

Eldridge, J., \& Crombie. (1974). The Sociology of Organization. London: Allen \& Urwin.

Eliade, M. (1959). Cosmos and history: The myth of the external return. New York: Harper and Row.

Fey, C. F., \& Denison, D. R. (2000). Organizational culture and effectiveness: The case of foreign firms in Russia. SSE/EFI working paper series in Business Administration, 2000(4).

Furnham, A., \& gunter, B. (1993). Corporate Assessment. London: Routledge.

Hellriegel, D., Jackson, S. E., Slocum, J., Staude, G., Amos, T., Klopper, H. B., Louw, L., \& Oosthuizen, T. (2004). Management (2nd Ed.). Cape Town: Oxford University Press Southern Africa.

Iverson, R. D., \& Roy, P. (1994). A causal model of behavioural commitment: evidence from a study of Australian blue-collar employees. Journal of Management, 20(1), 15-41. 
http://dx.doi.org/10.1177/014920639402000102

Kluckhohn, C. (1951). The concept of culture in the political sciences. Palo Alto, CA: Stanford University Press.

Kotter, J. P., \& Heskett, J. L. (1992) Corporate Culture and Performance. New York: Free Press.

Kpelai, S. T. (2009). Entrepreneurship development in Nigeria. Makurdi: Aboki Publishers.

Lahiry, S. (1994). Building commitment through organizational culture. Training and Development, 3, 50-52.

Lawrence, P. R., \& Lorsch, J. W. (1967). Organization and environment. Cambridge, MA: Havard Business School Press.

Lok, P., \& Crawford, J. (2001). Antecedents of organizational commitment and the mediating role of job satisfaction. Journal of Management Psychology, 16(8), 594-613. http://dx.doi.org/10.1108/EUM0000000006302

Lok, P., \& Crawford, J. (2004). The effects of organizational culture and leadership style on job satisfaction and organizational commitment. Journal of Management Development, 23(4), 321-338. http://dx.doi.org/10.1108/02621710410529785

Mahmudah, E. W. (2012). Effects of organizational culture and ability on organizational commitment and performance in Ibnu Sina hospital, Gresik. Academic Research International, 2(1), 349-355.

Mckinnon, J. L., Harrison, G. L., Chow, C. W., \& Wu, A. (2003). Organizational culture: Association with commitment job satisfaction, propensity to remain, and information sharing in Taiwan. International Journal of Business Studies, 11(1), 25-44.

Mclean, A., \& Marshal, J. (1993). Intervening in cultures. Working Paper, University of Bath.

Mead, G. H. (1934). Mind, self, and society. Chicago: University of Chicago Press.

Michaels, P. (1994). An expanded conceptual framework on organizational commitment and job satisfaction for sales force management. Journal of Business and Society, 7(1), 42-67.

Miller, V. L. (2004). An examination of contemporary marketing prospects used by organizations with different culture types: A test of the convergence theory in the US and Cote d' Ivorie. Unpublished $\mathrm{PhD}$ thesis, Robinson College of Business, Georgia State University, Atlanta.

Mitroft, I. I. (1984). Shareholders of the organizational mind. San Francisco: Jossey-Bass.

Mowday, R., Porter, L., \& Steer, R. (1982). Organizational linkage: The psychological of commitment, absenteeism and turnover. New York, Academic Press.

Mowday, R., Steers, R., \& Porter, L. (1979). The measurement of organizational commitment. Journal of Vocational Behaviour, 14, 224-227. http://dx.doi.org/10.1016/0001-8791(79)90072-1

Mowday, R. T. (1999). Reflections on the study and relevance of organizational commitment. Human Resource Management Journal, 8(4), 387-401.

Nazir, N. A. (2005). Person - culture fit and employee commitment in banks. Vikalpa, 30(3), 39-51.

Nongo, S. E. (2011). The impact of organizational culture on corporate effectiveness: A study of the cement manufacturing industry in Nigeria. Unpublished PhD thesis, Department of Business Management, Benue State University, Makurdi.

O'reilly, C. (1989). Corporations, culture and commitment: Motivation and social control in organization. California Management Review, 31(4), 9-25.

O'reilly, C. A., Chatman, J., \& Caldwell, D. F. (1991). People and organizational culture: A profile comparison approach to assessing person-organization fit. Academy of Management Journal, 34(3), 487-516. http://dx.doi.org/10.2307/256404

Peters, T., \& Waterman, R. (1982). In Search of Excellence. New York: Harper and Row.

Price, J., \& Mueller, C. (1981). Professional Turnover: The Case of Nurses. New York: Medical and Scientific Books.

Rowe, A. J., Mason, R. O., Dickel, K. E., Mann, R. B., \& Mockler, R. J. (1994). Strategic Management: A methodological approach (4th ed.). New York: Addison-Wesley.

Schein, E. H. (1992). Organizational culture and leadership (2nd ed.). San Francisco: Jossey-Bass.

Silverthorne, C. (2004). The impact of organizational culture and person-organization fit on organizational 
commitment and job satisfaction in Taiwan. The Leadership and Organization Development Journal, $125(7), 522-599$.

Steers, R. (1977), Antecedents and outcomes of organizational effectiveness. Administrative Science Quarterly, 22, 40-56. http://dx.doi.org/10.2307/2391745

Wasti, S. A. (2003). Organizational commitment, turnover intentions and the influence of cultural values. Journal of Occupational and Organizational Psychology, 76(3), 303-321. http://dx.doi.org/10.1348/096317903769647193 